\title{
MACROECONOMIC DETERMINANTS OF EXTERNAL DEBT ACCUMULATION IN ETHIOPIA: AN ARDL BOUND TESTINGAPPROACH
}

\section{Eyayu Tesfaye Mulugeta}

\author{
Lecturer, Department of Economics, Addis Ababa University \\ Email: eyayu.tesfaye@ aau.edu.et, tesfaye.mulu@gmail.com
}

Cite this article:

Eyayu Tesfaye Mulugeta (2021), Macroeconomic Determinants of External Debt Accumulation in Ethiopia: An ARDL Bound Testing Approach. African Journal of Economics and Sustainable Development 4(2), 1-28. DOI: 10.52589/AJESD-5CHIK2TR.

\section{Manuscript History}

Received: 16 April 2021

Accepted: 10 April 2021

Published: 19 July 2021

Copyright (c) 2020 The Author(s). This is an Open Access article distributed under the terms of Creative Commons AttributionNonCommercial-NoDerivatives 4.0 International (CC BY-NC-ND 4.0), which permits anyone to share, use, reproduce and redistribute in any medium, provided the original author and source are credited.
ABSTRACT: This study attempts to explore the major macroeconomic determinants of external debt stock growth in Ethiopia prompted by a continuous increase in government external borrowing over the period 1981-2018. For this purpose, the study employed the ARDL bound testing approach and all the necessary time series diagnostic tests were conducted. The long run model estimation result revealed that per capita GDP growth has a positive andsignificant effect on the country's external debt stock. The result also revealed that the budget deficit and political instability put a significant upward pressure on the external debt stock growth of the country both in the short run and long run. Consistent with some existing empirical evidence, the study revealed negative and significant influence of openness and infrastructure development on the external debt stock growth. Consequently, the government should embark on prudent borrowing to achieve structural transformation.

KEYWORDS: Economic Growth, External Debt Stock, ARDL Bound Testing, Ethiopia. 


\section{INTRODUCTION AND RATIONALE OF THE STUDY}

Ethiopia has continued to register relatively high economic growth over the past decade, with an annual average real GDP growth rate of $10.8 \%$ since $2004 / 05$ of which the huge government expenditure is the main driver of economic growth (ADB, 2018). According to the WB estimates from 2000 to 2018 Ethiopia was the third fastest-growing country of 10 Million or more people in the world as measured by GDP per capita. The main objective of the government's development strategy, anchored on its first Growth and Transformation Plan (GTP I), was to promote this economic growth through massive public-driven infrastructure investments. Building on GTP I, GTP II also aims to transform Ethiopia into an industrialized middle-income country by 2025 . The plan places a key emphasis on private sector development and FDI in building an export-oriented manufacturing sector to increase the diversification of exports and support resilient growth (FDRE, 2016).

Following the state-led development program of the government, the ratio of debt to GDP has been increased to 33.5 percent in 2017 from 26.9 percent in 2008. A report of the World Bank (2019) indicates that Ethiopia recorded a government debt equivalent to 60 percent of the country's Gross Domestic Product in 2018. Government Debt to GDP in Ethiopia averaged 34.57 percent from 1991 until 2018, reaching an all-time high of 60 percent in 2018. This casts a serious concern related to the sustainability of development. As per the IMF (2018) projection, the ratio will be 59.8, 66.4, and 73.9 percent in 2020, 2021, and 2022 respectively, which has put the country's Debt Sustainability Analysis (DSA) at high risk.

The key risk associated with accruing external debt is that the external debt may exceed a sustainable level vis-à-vis national repayment capabilities. The existing literature on external debt determinant shows that a macroeconomic, political, institutional, and structural variable affects the level of external debt. According to Sinha et al. (2011) and Swamy (2015) economic growth, inflation, financial sector development and the level of FDI are the main indicators that impact the size of external debt. The level of political instability, corruption, and quality of the bureaucracy has also a great impact on the external debt level (Lavigne, 2011 and Cooray et al. 2016). According to Veiga and Veiga (2014), the growth of public debt can also be stimulated by structural factors suchas level unemployment and a proportion of the aging population which puts strong upward pressure on public expenditure

Several studies have been conducted on the effect of the external debt burden on economic growth and export performance in Ethiopia. The study by (Alemayehu and Daniel ,1998; Hassan et al 2014) reveals that Ethiopia's foreign debt has been increasing in its magnitude and has become large relative to the size of the economy and the level of exports. In addition to this, Befekadu (1992) also employed a growth-debt model for Ethiopia and concluded that external debt has adversely affected economic growth. Even though the debt service/export ratio is low and has declined in the later years in Ethiopia, the country faces a severe debt/GDP ratios. Moody's (2014) makes an observation that Ethiopia's sovereign debt rating could go down if there is acceleration of external debt that does not support growth. Garedew (2018) assess the effect of external debt on the economic growth of Ethiopia and found that in the long-run the external debt negatively and significantly affects the economic growth of Ethiopia. 
This paper is distinguished from the previous works in several aspects. First, the study is motivated by the fact that to the best of our knowledge, no previous study empirically investigated the short- run and long-run effect of Ethiopian economic growth on external debt stock growth. Second, effecting of major macroeconomic variables such as political instability, infrastructural development, age dependency ratio, and financial sector development on growth of external debt stock has not been assessed so far. Third, we employ the ARDL bound testing approach to explore the extent to which the economic growth influences the external debt stock of the country in the long run. Furthermore, the study is timely given Ethiopia's extensive use of external borrowing from international institutions to finance its budget deficit. Therefore, this paper is aimed at examining the short and long-run relationship between economic growth and Ethiopia's growth of external debt stock prompted by continuous increases in government external borrowing. The studyis aimed also at analyzing the major macroeconomic determinants of external debt stock which are overlooked by the previous studies.

\section{LITERATURE REVIEW}

\section{Theoretical Literature}

Governments may accumulate debt to support public and profitable investment in physical infrastructures, human resources, education and healthcare among others. Public debt allows governments to smooth and redistribute tax burdens over time and across generations. High public debt and large fiscal deficit are a common feature among countries in Sub Saharan Africa. As the states have limited capacity to generate revenue they are forced to borrow to meet their fiscal deficit, and higher fiscal deficit causes a higher incidence of indebtedness. A growing debt ratio implies that public expenditure is excessively devoted to unproductive spending primarily because of inefficient fiscal management of the state governments (Cukierman and Meltzer, 1989).

According to Elmendorf and Mankiw (1999), public external debt can be analyzed through the conventional perspective or the Ricardian equivalence theory. The Ricardian approach emphasizes the irrelevance of the debt, while the conventional view highlights the aggregate demand in the short period with the effect of crowding out. It asserts that the level of government external debt is not important and does not have any effect on the economy. It is based on the assumption that a reduction in tax is equal to an increase in debt level. If the government reduces taxes now, society should know that taxes would be increased in the future. Thus, citizens would not consume more, but instead, they would be saving more to pay the future tax and the budget deficit will coincide with an increase in private saving in the framework of the combination of government budget constraint and the permanent income hypothesis

The government budget constraint explains that lower taxes today mean higher taxes tomorrow keeping a stable level of government spending. The permanent income hypothesis claims that consumers make their decisions on their income evaluated in the long run. The foreign debt burden is an indication of somber problems in the economy where the country is incapable to finance its resource gaps, has exchange rate problems, and/or its productivity is low. Countries that followed structural adjustment programs are even more exposed to huge foreign debts than ever before. In general, theories show a positive relationship between a 
reasonable amount of debt for capital scarce countries that benefit in the wake of capital inflows. However, the literature also links larger inflows of debt with lower economic growth.

Chenery and Strout (1966) assert that this finance in the form of aid contributes to growth by discharging some of the possible blockages of savings and foreign exchange. However, several debt-ridden African countries observed sluggish growth in the late 1970s and early 1980s. This sluggish growth caused poverty and inability to pay foreign liabilities. Alemayehu (1997) displays that debt to GDP ratio of Africa has grown from 22 percent in 1972 to 130 percent in 1992. The well-known debt overhang hypothesis is a case in point. It is revealed that the anticipated debt service (which is interesting and principal on the debt) is an increasing function of a country's output level. The returns from investing in-country, therefore, face a high marginal tax by the external creditors, and new domestic and discouraged foreign investment. (Krugman, 1988; Sachs, 1989; Salih, 1994) inquires into the growth-debt linkage in Africa and present evidence that is consistent with the debt overhang literature.

Following the burden of debt, Sub-Saharan Africa has received external debt burden reduction, among other things, in the form of the provision of concessional financing from international financial institutions, debt relief from official creditors mainly in the context of Paris Club rescheduling, and, in some cases, through bilateral action by the creditors. Though these measures have resulted in considerable success in alleviating the external debt burdens of many middle- income countries, the countries in sub-Saharan Africa continue to suffer from unacceptable levels of poverty and heavy external debt burdens (IMF, 2001). Corden (1989) and Helpman (1989) note that debt forgiveness may upsurge investment by declining future debt payments. Oxfam International (1997) reveals that African debt servicing absorbs one quarter to one-third of foreign exchange earnings, diverting the resources from investment.

\section{Empirical Literature}

Several countries and cross-country studies have been done by many economists and researchers to assess the macroeconomic determinants of external debt. The existing literature on public debt determinant shows that economic factors such as economic growth, inflation, debt service payment, budget deficit, public spending, the credibility of monetary policy, and degree of openness can influence the trajectory of debt (Imbeau and Pétry, 2004). The level of political instability, corruption, and quality of the bureaucracy has also a great impact on the public debt level (Lavigne, 2011). The more politically unstable a country is, the larger will be its budget deficit.

The growth of public debt can also be stimulated by structural factors such as level unemployment and the proportion of the aging population, which puts strong upward pressure on publicbexpenditure which in turn boosts public debt. Swamy (2015) used Panel Granger causality method and found that real GDP growth, foreign direct investment, government expenditure, inflation and population growth have a negative effect on debt. Using panel regression, Sinha et al. (2011) confirmed that the main indicators that impact the size of sovereign debt are economic growth, interest rates, inflation, the level of current account balance and the level of FDI. Matosec (2016) analyze public debt determinants in EU new member states. The results showed that by achieving a more balanced government budget, the growth rate of public debt should decrease. 
Uzun, et al., (2012) found a positive relationship between external debt and the growth rate of transition countries in the long run. Checherita and Rother (2010) also found a non-linear impact of public debt on growth with a turning point beyond which the government debt to GDP ratio has a deleterious impact on long-term growth at about $90-100 \%$ of GDP. Their finding also revealed that the negative growth effect of high debt may start already from levels of around 70-80\% to GDP ratio. The public debt to GDP ratio negatively and linearly associated with per-capita GDP growthin their study.

Economic theory provides little practical guidance on the optimal level of public debt. However, empirical studies show that if debt exceeds 50 percent of a country's GDP, then, the further rise can be harmful (Fry 1989). The study by Reinhart and Rogoff (2010), analyzed the developments of public debt and the long-term real GDP growth rate in a sample of 20 developed countries through simple correlation statistics over nearly 200 years (spanning from 1790 to 2009). They found that the relationship between government debt and long-term growth is weak for debt/GDP ratios below a threshold of $90 \%$ of GDP; above $90 \%$, the median growth rate falls by one percent and the average by considerably more. Reinhart and Rogoff (2013) also concluded that economic growth in emerging economies suffers once the debt-to-GDP ratio hit a threshold of 60 per cent. Other researches carried out within the specific context of developing and low income countries suggest a much lower (30 -40 per cent) threshold of debt-to GDP ratios

A study by Jonse (2002) investigated the impact of external debt on economic growth in Ethiopia and the result indicated that external debt affects investment positively and is statistically significant. Hailemariam (2010) investigated the existence of the long run relationship between external debt and growth in Ethiopia. He explores that the current level of external debt flow has a positive while the past debt accumulation has a negative impact on growth and private investment. Melese (2005) used a structural macroeconomic mode and found that all debt burden indicators

have a negative relationship with economic growth in Ethiopia. Mulugeta (2014) studied the impact of external debt on economic growth in Ethiopia over the period 1983-2013 using Johansen maximum likelihood and vector error correction (VECM) model and found the existence of the negative long run relationship between RGDP and Debt.

\section{METHODOLOGY AND DATA}

Data used in this study is extracted from World Development Indicators, Africa Development Indicators, International Monetary Fund, World Bank, National Bank of Ethiopia, International Country Risk Guide and the Ministry of Finance and Economic Cooperation databases. The temporal scope of the study is restricted in 1980-2018 due to the unavailability of the data for some of the variables before 1980. Time series Econometrics and descriptive methods of data analysis techniques were applied to systematically analyze the data. Econometric analysis is mainly used to investigate the structure and magnitude of major macroeconomic determinants of external debt accumulation in Ethiopia. Descriptive analysis is also used to analyze the evolution of external debt stock, external debt to GDP ratio and debt service to export ratio among others. 


\section{Model Specification}

To examine major macroeconomic determinants of external debt accumulation in Ethiopia the model employed by Belhuith and Omrane (2017) and Matitti (2013) was adopted with some modifications by including relevant variables as highlighted in the literature. Thus, the extended version of the linear model is given as:

$$
\begin{aligned}
& E D t=+Q_{1} P C G D P t+Q_{3} B D F t+Q_{40 P E N t}+Q_{5} I N F R A t+Q_{6} A D R t+Q_{7 F S D t}+ \\
& \mathrm{Q} 8 \boldsymbol{P S} \boldsymbol{t}+\varepsilon t-(1)
\end{aligned}
$$

Where $E D$ is External Debt Stock expressed as \% of GDP , PCGDP is Percapita GDP growth (annual \%), BDF is budget Deficit as \% of GDP, OPEN is trade openness measured by trade as share of GDP (\%), INFRA is Infrastructure development measured by the fixed telephone subscriptions per 100 people, $A D R$ is Age dependency ratio, old (\% of working age population), FSD is financial development measured by the GDP share of broad money supply (M2), PS is political instability index based on International Country Risk Guide and $\varepsilon$ is error term.

To investigate the existence of cointegration among the variables, this paper adopts one of the contemporary time series techniques of analysis called the Autoregressive Distributed Lag (ARDL) model which was established by Pesaran and Shin (1999) and later extended by Pesaran et al (2001). Compared to the Johansen cointegration test, developed by Johansen and Juselius (1990), the ARDL bounds test yields more desirable effects and therefore is used commonly for empirical modeling. The advantages of using the ARDL technique instead of the conventional Johansen (1998) and Johansen and Juselius (1990) cointegration approach is that while the latter estimates the long-run relationships within the context of a system of equations, the former employs only a single reduced from equation (Pesaran and Shin 1995). Besides, the ARDL method avoids configuring a larger number of specifications in the standard cointegration test.

Furthermore, the ARDL approach allows the use of different optimal lags for the different variables which is not possible in the standard cointegration test (Bekhet and Matar (2013). The ARDL approach also enables the simultaneous identification of the short and long-term effects of a variable (Bentzen \& Engster, 2001). These advantages motivate the choice of ARDL procedure in investigating the relationship between the variables. The fact that the stability of variables stands at I (1) shows that the ARDL model is suitable for use. An adapted version of the Peseran et al. (2001) model for our study the ARDL approach to cointregation is provided below:

$$
\begin{aligned}
& \Delta E D_{t}=Q_{0}+Q_{1} \Delta P C G D P+Q_{2} \Delta B D F+Q_{3} \Delta O P E N+Q_{4} \Delta I N F R A+Q_{5} \Delta A D R+Q_{6} \Delta F S D \\
& +Q_{7} \Delta P S+a_{1}(E D)_{t-1}+a_{2}(P C G D P)_{t-1}+a_{3}(B D F)_{t-1}+a_{4}(O P E N)_{t-1} \\
& +(I N F R A)_{-1}+a_{6}(A D R)_{t-1}+a_{7}(F S D)_{t-1}+a_{8}(P S)_{t-1}+E C T_{t-1}--(2)
\end{aligned}
$$


To obtain the optimal number of lags for each variable, a lag length test is conducted by estimating single equation Vector Autograssive (VAR) and using the lag length criteria. This is followed by the estimation of a single equation unrestricted Error Correlation Model (ECM) with the number ofestimated lags as shown in the following Equation (3)

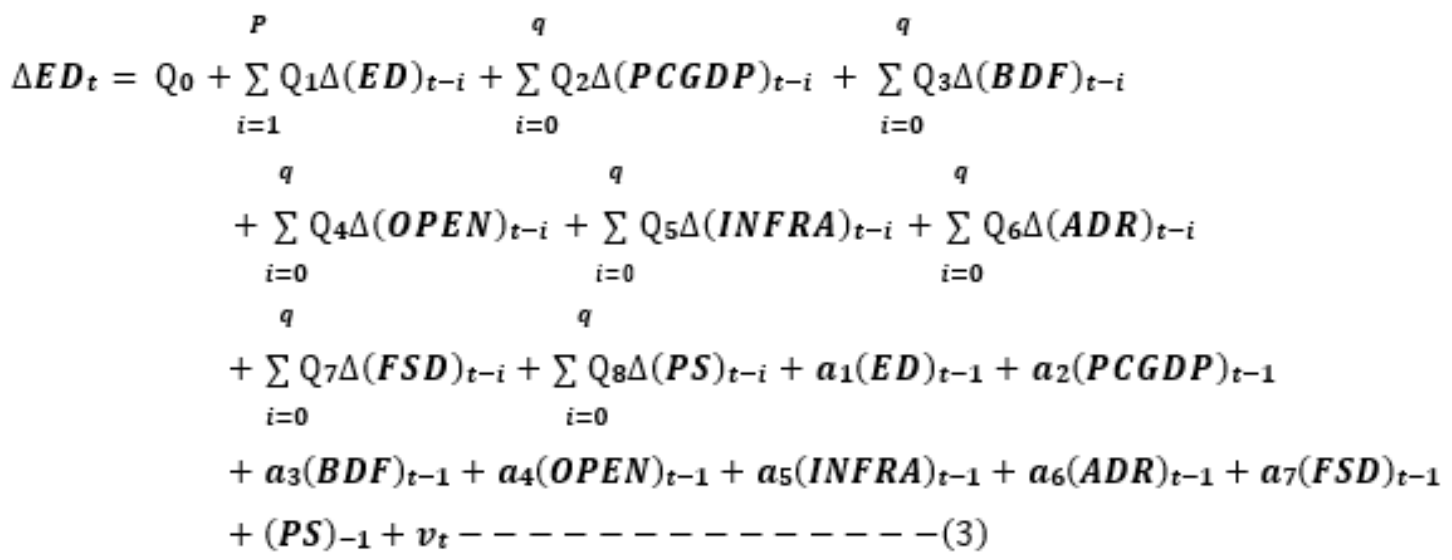

Here, $\Delta$ represents the first-level difference, $P$ and $q$ are the optimal lag orders of the dependent and independent variables respectively. Parameters $\left(1-\beta_{8}\right)$ represents short run dynamic coefficients of the model, $\left(a_{1}-a_{8}\right)$ represents the long run parameters and $\boldsymbol{v}_{\boldsymbol{t}}$ is a white noise error term. Wald tests on the coefficients of long run variables will be conducted to obtain F-statistics, which are used as the boundary tests for cointegration. When an Fstatistic is above the upper bound value, we reject the null hypotheses of no cointegration among the variables.If it falls below the lower bound value, we do not reject the null hypotheses of no cointegration. The hypothesis of the bounds test in the above equation (3) is

$H_{0}: a_{1}=a_{2}=a_{3}=a_{4}=a_{5}=a_{6}=a_{7}=a_{8}=0$

$H_{A}: a_{1} \neq a_{2} \neq a_{3} \neq a_{4} \neq a_{5} \neq a_{6} \neq a_{7} \neq a_{8} \neq \mathbf{0}$

If the variables are cointegrated then there may be disequilibrium in the short-run and error correction mechanism is used to correct the dis-equilibrium. The short-run dynamics can be derivedby estimating the Error Correlation Term (ECT) with the specified lags as :

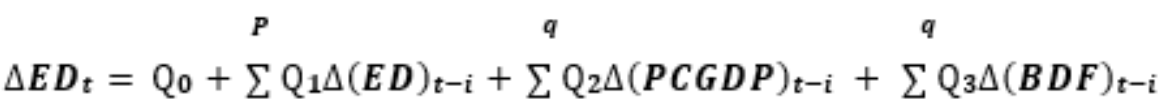

$$
\begin{aligned}
& { }_{q}^{i=1} \quad i=0 \quad q \quad i=0 \quad q \\
& +\sum Q_{4} \Delta(\text { OPEN })_{t-i}+\sum Q_{5} \Delta(\text { INFRA })_{t-i}+\sum Q_{6} \Delta(A D R)_{t-i} \\
& \underset{q}{i=0} \quad q^{i=0} \quad i=0 \\
& +\sum_{i=0} Q_{7} \Delta(F S D)_{t-i}+\sum_{i=0} Q_{8} \Delta(P S)_{t-i}+B{ }_{9} E C T_{t-1}-----(4)
\end{aligned}
$$


Where $E C T_{t-1}$ is the error correction term and the coefficient $B 9$ represents the speed of adjustment parameter (Ada and Kharusi, 2018).

\section{EMPIRICAL ANALYSIS}

\section{Descriptive Analysis}

\section{Evolution of the Ethiopian Debt-to-GDP Ratio}

Ethiopia recorded a government debt equivalent to 61 percent of the country's Gross Domestic Product in 2018. Government Debt to GDP in Ethiopia averaged 34.57 percent from 1991 until 2018, reaching an all-time high of 61 percent in 2018 and a record low of 24.70 percent in 1997. In the year 2018, public debt was 48.9 billion dollars and increased by 14.5 billion as compared to 2015. The position of Ethiopia as compared with the rest of the world has worsened in 2018 in terms of GDP percentage (IMF, 2019).

As shown in the table below, the evolution of debt shows a rising trend in absolute terms since the year 2010 which was 12.1 billion ( $40.5 \%$ of the GDP) to $48 . .9$ billion in the year 2018 (61\% of the GDP). Moreover, the per capita debt of the country was 139 dollars in the year 2006 which increases to 383 dollars in the year 2015. In the year 2018, the per capita debt of Ethiopia rises to 449 dollars. This evolution of the external debt comes as a result of the low levels of financial sector development, the dysfunctions of the domestic economy, the low level of competition across sectors, absence of regulation in state borrowing and the need to obtain foreign currency to finance the balance of payments, among others. According to Africa Economic Outlook (2018) although the domestic revenue mobilization improved substantially in recent decades, tax-to-GDP ratios are still below the 25 percent threshold deemed sufficient to scale up infrastructure spending.

A growing debt ratio implies that public expenditure is excessively devoted to unproductive spending primarily because of inefficient fiscal management of the state governments (Cukierman and Meltzer, 1989. According to Alemayehu (2020) an estimated \$10 billion loan for the ongoing "liberalization" policy and additional money to fight the effect of the COVID-19 could push the external debt to GDP ratio from the current level of 28 percent to over 45 to 50 of the official GDP and it could even become over 70 percent of GDP if the official GDP data were not exaggerated.

\section{Table 1: Evolution of Public Debt in Ethiopia}

$\begin{array}{llll}\text { Year } & \text { Debt (Billion USD) } & \text { Debt }(\% \text { GDP) } & \text { Debt Per capita (\$) } \\ 2018 & 48.9 & 61.0 & 449 \\ 2017 & 44.4 & 58.6 & 417 \\ 2016 & 39.7 & 56.0 & 436 \\ 2015 & 34.4 & 54.5 & 383\end{array}$




$\begin{array}{llll}2014 & 25.9 & 47.8 & 293 \\ 2013 & 22.1 & 47.5 & 254 \\ 2012 & 17.8 & 42.2 & 208 \\ 2011 & 14.5 & 45.3 & 172 \\ \mathbf{2 0 1 0} & 12.1 & 40.5 & 146\end{array}$

Source: IMF (2018) https://countryeconomy.com/national-debt/ethiopia

\section{Composition and Trend of External Debt Stock}

Ethiopia has relied on concessional debt, particularly external loans from multilateral partners and official bilateral creditors, and commercial loans from non-traditional creditors such as China to finance its infrastructure projects. As shown in the figure 1 below, Ethiopia's external debt stock has shown a continuous increment since 2010 and reached USD 26.6 billion in 2017 depicting 11.3 percent annual growth largely due to higher debt owed to multilateral and commercial creditors. According to UNDP (2018), the increase in external debt stock in 2017 is partly attributable to larger than planned net resource flows resulting from new external project loans disbursements from IDA, Exim-Bank of China, as well as borrowings by SOE's from commercial and suppliers' creditors during the year indicated.

Between 2013/14 and 2017/18, the relative share of multilateral creditors has slightly declined while the relative share of bilateral and private creditors increased. Currently, out of the total external debt, creditors from China take the top share, followed by IDA as the major creditors, with $34 \%$ and $30 \%$ of the total external debt outstanding owed to those creditors respectively. When we looked at the past five years trends in detail, total public debt outstanding (external and domestic)

has significantly increased. The sharp increase in the external debt stock has primarily been drivenby huge import-intensive public enterprise investments and weak export performance (ADB, 2018) In the last five years the volume of debt stock increased by $87.3 \%$. The major reason for thisincrement in the stock of public debt was an increase in disbursement from both external anddomestic sources (IMF, 2018). 


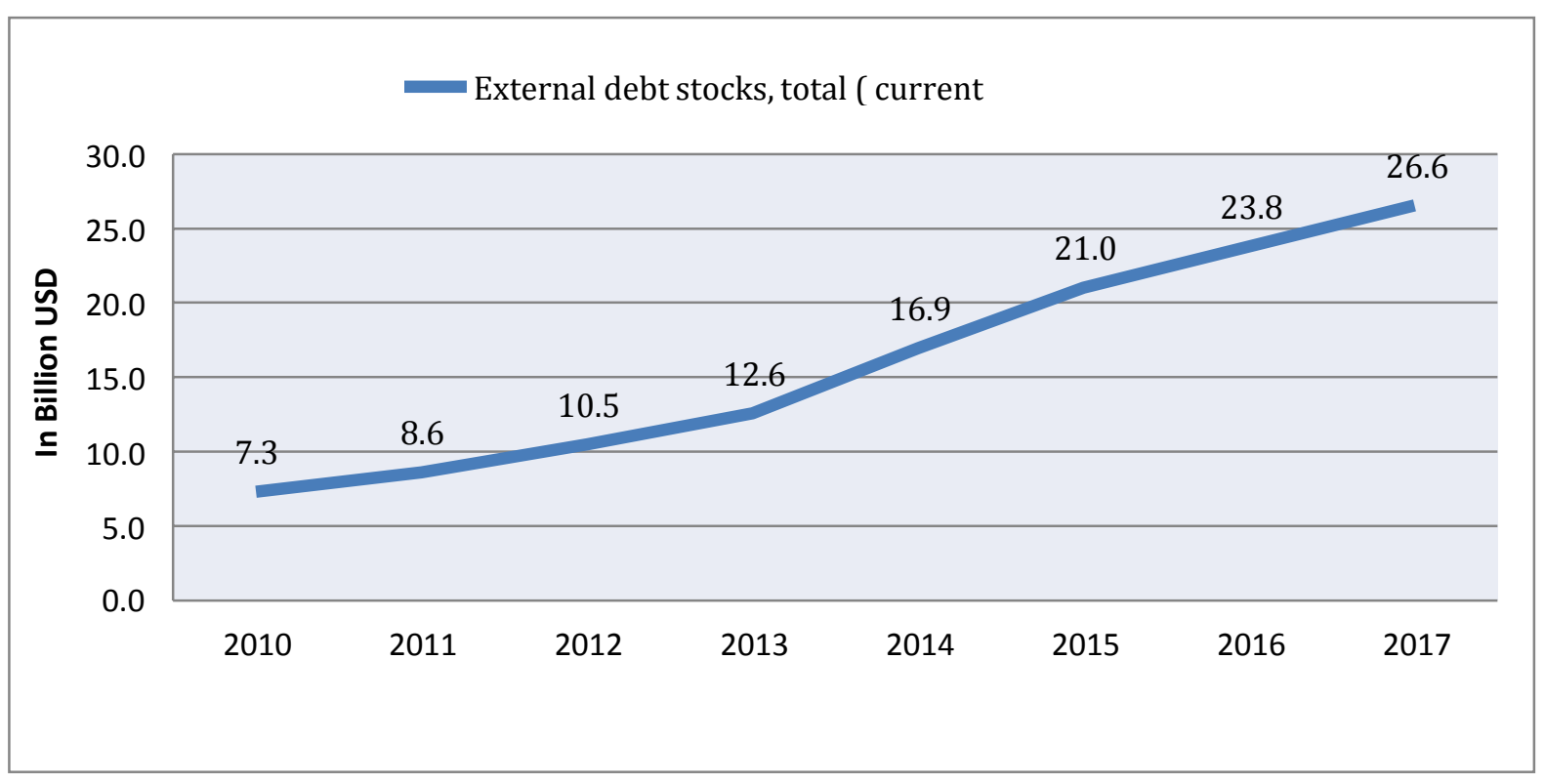

Figure 1: Trend of Total External Debt Stocks in Ethiopia

Source: WDI and IMF Database (2019)

\section{Trend of External Debt services}

As shown in the figure 2 below, the general trend in the debt service payment also shows a significant increment throughout the observation period. The country's external debt stock to GNI ratio stood at 33.2 percent in the year 2017. The country's external debt burden as measured by debt services to export of goods and non-factor service ratio marginally increased to 20.8 percent in 2017 from 17.2 percent in the year 2015. According to Alemayehu (2020) Ethiopia's debt services have increased in the last three years and becoming an average almost US\$ 2 billion per annum, which is two-third of our merchandise exports and nearly a third of exports of goods and nonfactor services. He also reiterates that the COVID-19 effect will raise this figure to 38 percent. During the year 2017 principal payment was USD $72 \%$, while the payment for interest and commission was 28 percent. As a result of the ETB devaluation against USD in October 2017, the external debt service in terms of ETB has risen significantly. Debt service payments are expected to increase in the coming years as grace periods on non-concessional debt acquired in the past expire. In relation to this, the MOFEC has announced that no new projects will be financed with nonconcessional debtin 2017 (MOFEC, 2018). 


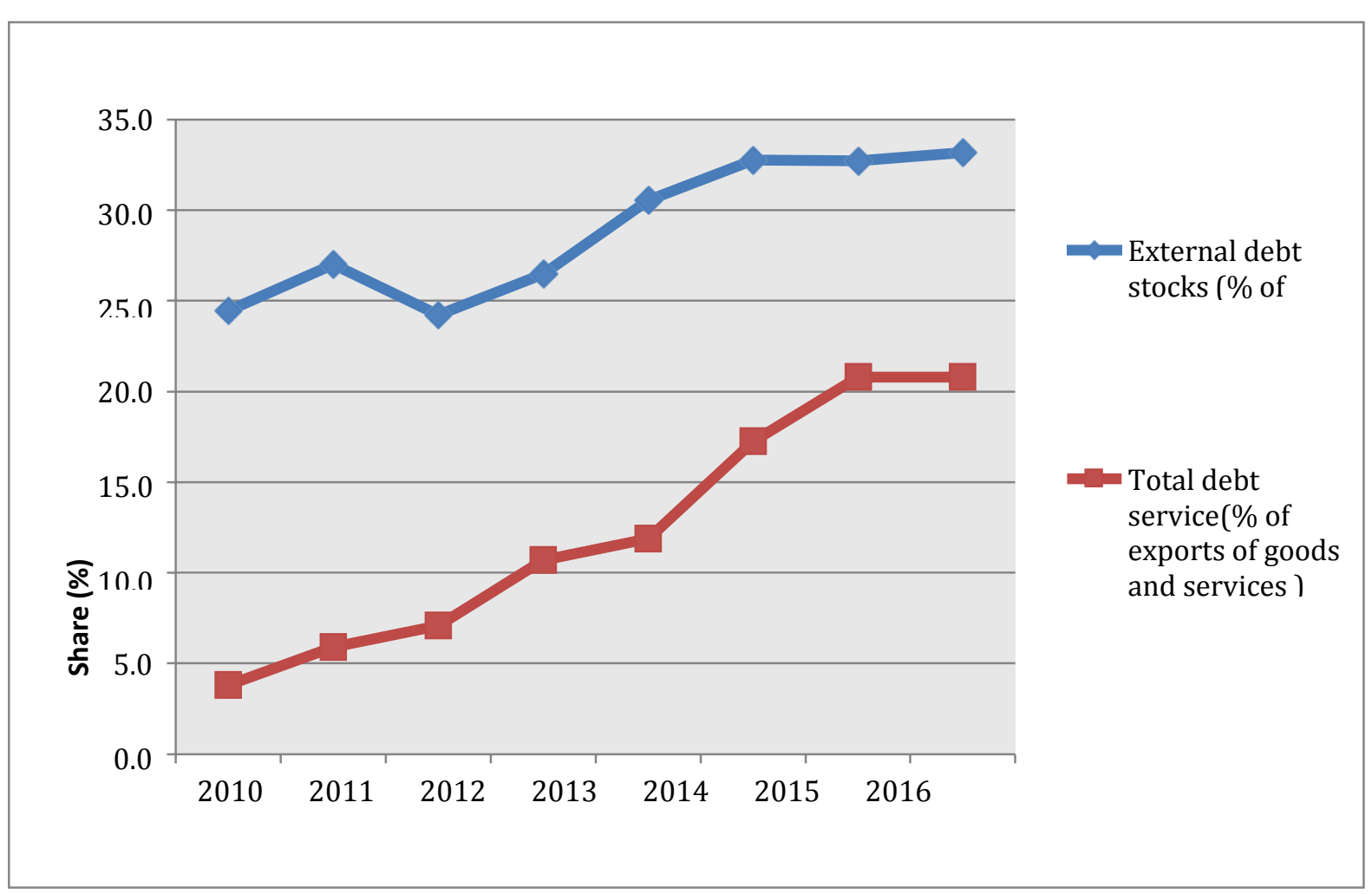

Fig. 2: Trends in the share of Debt Stock and Debt Service

Source: WDI and IMF Database (2019)

\section{Econometric AnalysisDiagnostic Analysis}

Following the standard procedure in time series Econometrics, a stationary test is first conducted using the ADF test to determine the order of integration for each variable. A prerequisite for the ARDL bounds testing is that the series under review stands at levels $\mathrm{I}(0)$ or I(1). An augmented Dickey-Fuller (ADF) test is adopted to analyze the stability of the variables. Since the stationary property of the variables under consideration is a mixture of my (1) and I (0) the ARDL bound testing technique was deemed appropriate for estimation Alemayehu et al. (2012).

Table 2: ADF Unit Root Test

\begin{tabular}{|l|l|l|l|}
\hline \multicolumn{4}{|l|}{ Augmented Dickey-Fuller Test } \\
\hline Variables & Level & First Difference & $\mathrm{I}(\mathrm{d})$ \\
\hline LNED & -1.415 & $-4.703^{*}$ & $\mathrm{I}(1)$ \\
\hline LNPCGDP & 0.915 & $-3.443^{* *}$ & $\mathrm{I}(1)$ \\
\hline OPEN & -1.130 & $-4.4 .927^{*}$ & $\mathrm{I}(1)$ \\
\hline BDF & $-2.977^{* *}$ & $-2.955^{* *}$ & $\mathrm{I}(0)$ \\
\hline INFRA & -0.064 & $-3.341^{*}$ & $\mathrm{I}(1)$ \\
\hline
\end{tabular}


African Journal of Economics and Sustainable Development

ISSN: $2689-5080$

Volume 4, Issue 2, 2021 (pp. 1-28)

www.abjournals.org

\begin{tabular}{|l|l|l|l|}
\hline PS & -1.623 & $-5.863^{*}$ & $\mathrm{I}(1)$ \\
\hline ADR & -1.079 & $-3.106^{* *}$ & $\mathrm{I}(1)$ \\
\hline FSD & -1.717 & $-6.978^{*}$ & $\mathrm{I}(1)$ \\
\hline UNP & -1.686 & $-5.588^{*}$ & $\mathrm{I}(1)$ \\
\hline
\end{tabular}

Note: Critical values $1 \%$ and $5 \%$ are represented by $*$ and $* *$, respectively.

The first step in the ARDL approach is to select the appropriate lag length for co-integration by using VAR (Vector Auto Regressive) test based on Schwarz Bayesian Criterion (SBC) and Akaike Information Criterion (AIC) optimal lag length selection criteria. The VAR estimation, test recommended to lag to be the optimum lag length for this model (See Annex $3)$.

Table 3: Diagnostic Test Results

\begin{tabular}{|l|l|l|}
\hline Selected Model & \multicolumn{2}{|l|}{ ARDL(2, 0, 2, 0, 1, 2, 1, 2, 2) } \\
\hline K & \multicolumn{2}{|l|}{} \\
\hline F-statistics & 9.15 & I(1) Bound \\
\hline Critical Values & $\mathrm{I}(0)$ Bound & 4.1 \\
\hline $1 \%$ & 2.79 & 3.39 \\
\hline $5 \%$ & 2.22 & 3.06 \\
\hline $10 \%$ & 1.95 & \\
\hline Diagnostic Tests (P-Values) & 0.673 \\
\hline Normality Test & 0.873 \\
\hline RESET Test & 0.173 \\
\hline LM Test & 0.709 \\
\hline ARCH Test & 0.999 \\
\hline Chow test & 0.89 \\
\hline Adjusted R-Squared & \\
\hline
\end{tabular}

* P-Values are Prob (F-Statistic)values

The diagnostic test results of the ARDL model are given in the above table. The F statistics for the ARDL model is 9.15, which exceeds the upper bound 4.1 when evaluated at significance level of $1 \%$, implying that there is a cointegration in the ARDL model. The Ramsey RESET test is used to analyze whether or not the ARDL model has been installed with the correct specifications. Based on the results of the RESET test, it can be observed that the estimation result is significant and hence the model is well specified. The JarqueBera Normality test is used to analyze whether the distribution of error terms is normal or not. The test result points out that the error term of the model is normally distributed. The Chow test allows us to test whether a particular date causes a break in the regression coefficients. The chow breakpoint test is used to check whether the 2008 financial crisis causes a break in the regression coefficients or not. The result shows that we fail to reject the null hypothesis of no breaks at the specified breakpoint. 
The Breusch-Godfrey Lagrange Multiplier is also used to test whether there is autocorrelation in the model or not. The null hypothesis of the test is that there is no autocorrelation and the test result shows that we fail to reject the null hypothesis implying that the model has no problem of autocorrelation. The Auto Regressive Conditional Hetroskedasticity (ARCH) test is used to test the problem of changing variance or hetroscedasticity. Failure to reject the null of no ARCH indicates the existence of constant variance or there is no problem of changing variables. Cumulative sum (CUSUM) and the cumulative sum of squares (CUSUMQ) tests are used to check the stability of the model. The figures below support the stability of the model at the $5 \%$ level because the blue line never deviate beyond the critical red lines.

\section{Model Stability Test}

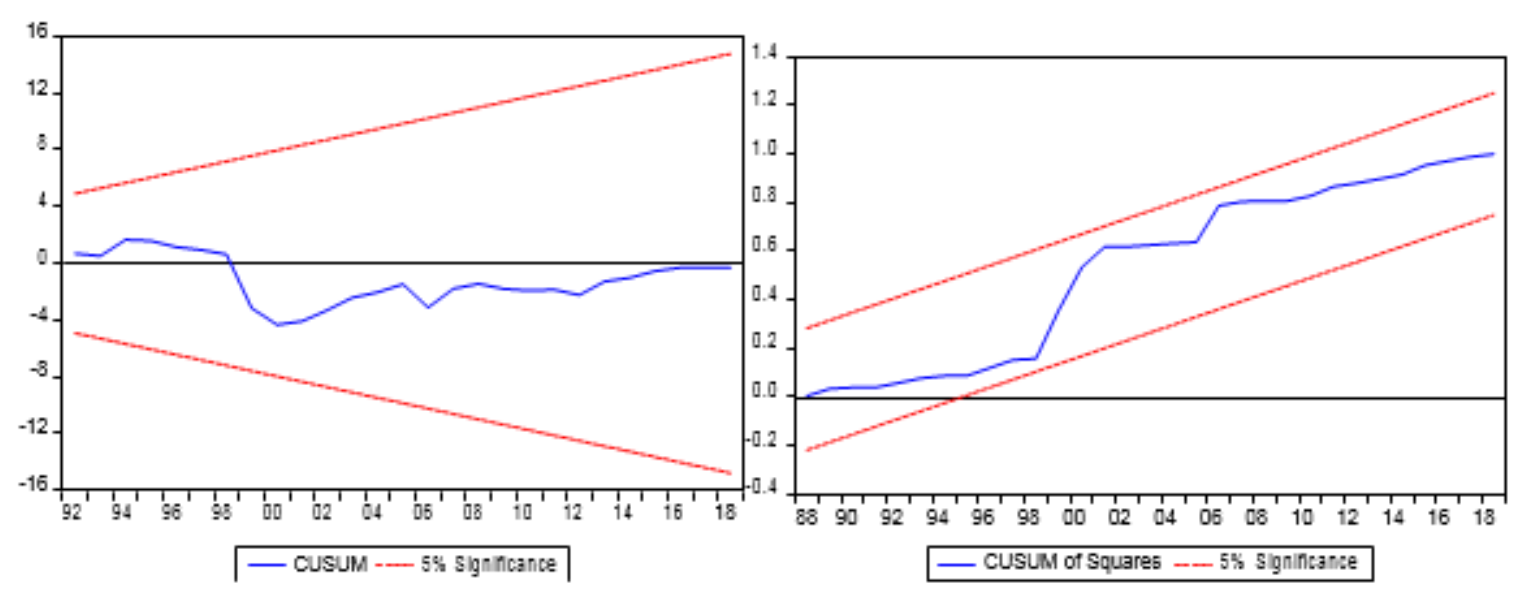

\section{RESULTS AND DISCUSSION}

\section{Long-Run Dynamics}

\begin{tabular}{lllll} 
& \multicolumn{2}{l}{ Dependent Variable LNED } & & \\
Variable & Coefficient & St. Error & t-Statistics & Prob. \\
\hline LNPCGDP & $0.270374 *$ & 0.154260 & 1.752713 & 0.1000 \\
\hline OPEN & $-0.020177 * *$ & 0.007596 & -2.656149 & 0.0180 \\
\hline INFRA & $-0.226115^{* * *}$ & 0.038301 & -5.903694 & 0.0000 \\
\hline BDF & $0.142669 * * *$ & 0.033446 & 4.265707 & 0.0007 \\
\hline UNP & $-0.278970 * *$ & 0.114452 & -2.437437 & 0.0277 \\
\hline PS & $0.136530 * *$ & 0.049763 & 2.743573 & 0.0151 \\
\hline ADR & 1.054356 & 0.693694 & 1.519915 & 0.1493 \\
\hline FSD & 0.016012 & 0.016145 & 0.991750 & 0.3370 \\
\hline C & -1.269409 & 3.663362 & -0.346515 & 0.73338
\end{tabular}

Note: Critical values $10 \%, 5 \%$ and $1 \%$ are represented by $*$, **, and $* * *$ respectively. 
The long run model estimation result revealed that per capita GDP growth $(P C g d p)$ has as a positive and significant effect on the growth in external debt stock of the country. This reiterates that although the economy has been growing at a remarkable rate the looming macroeconomic imbalance combined with low domestic resource mobilization leads to growing debt dependence of the Ethiopian economy even in the long run. According to the IMF (2018) the stagnated productivity growth caused by unproductive public spending aggravates country's increasing reliance on external borrowing and hence risk of external debt distress reaches at a high level. In hisrecent study, Alemayehu (2020) also revealed that if the country is managed to secure loans from international financial institutions, both to tackle the effect of COVID-19 and finance the new economic policy there will be a significant increase in the debt to GDP ratio.

Trade openness (Open) has a negative and statistically significant effect on growth in external debt stock in the long run.The result is in line with the theoretical proposition of open countries are more successful in attracting foreign investors into the domestic market, which is the biggest factor behind reducing debt dependence of the economy (Calvo et al., 2003). The exposition to marketing

strategies, production process and distribution network of multinationals will enhance the productivity of domestic firms in the long run. Therefore, degree of openness significantly improves the productivity of domestic manufacturing firms through horizontal FDI spillovers (Ermias, 2013).

The long run estimation result also confirmed that the looming government budget deficit $(b d f)$ of the country creates upward pressure on growth of external debt stock of the country. According to NBE (2018) the ratio of total government revenue to GDP remained flat while the ratio of expenditure to GDP ratio increased in the last decade, leaving the Ethiopian government with no option but to rely on deficit financing through external borrowing.

The coefficient of political instability shows a positive and significant effect on the growth of the external debt stock. This reiterates that the political instability observed in the last few years combined with the rampant corruption in the country highly increases the government expenditure and hence accumulation of external debt stock. Roubini and Sachs (1989) argue that political fragmentation is a potential cause of the presence of persistent deficits and hence increase external borrowing.

Infrastructural development (Infra) negatively influences the level of external debt in Ethiopia in the long run. This might be attributed to the public infrastructure investment on mega projects will enhance productivity and build repayment capacity of the country in the long run. The relative increase in government expenditure has been witnessed in recent years is attributed to rising spending on pro-poor and growth enhancing sectors which can improve productivity and reduce dependence in external debt in the long run. Though it is insignificant the coefficient which shows the positive effect of the age dependency ratio of public debt is correct stating that the rising number of the aging population in Ethiopia contributes to the growing debt burden through government subsidies and transfers. 


\section{Short Run Dynamics}

\begin{tabular}{|c|c|c|c|c|}
\hline \multicolumn{4}{|c|}{ Dependent Variable D(LNED) } & \multirow[b]{2}{*}{ Prob. } \\
\hline Variable & Coefficient & St. Error & t-Statistics & \\
\hline D(LNPCGDP) & 0.208702 & 0.138762 & 1.504026 & 0.1533 \\
\hline D(OPEN) & -0.008619 & 0.008093 & -1.065032 & 0.3037 \\
\hline D(INFRA) & $-0.174538 * * *$ & 0.058305 & -2.9993537 & 0.0091 \\
\hline D(BDF) & $0.080192 * * *$ & 0.015210 & 5.272314 & 0.0001 \\
\hline D(UNP) & $-0.562571 * * *$ & 0.091113 & -6.174417 & 0.0000 \\
\hline D(PS) & $0.211866^{* * *}$ & 0.032012 & 6.618251 & 0.0000 \\
\hline D(ADR) & 0.660691 & 0.799595 & 0.826282 & 0.4216 \\
\hline D(FSD) & $0.026754 * * *$ & 0.006248 & 4.586426 & 0.0004 \\
\hline ECT(-1) & $-0.771901 * * *$ & 0.152019 & -5.077668 & 0.0001 \\
\hline
\end{tabular}

Note: Critical values $1 \%$ and $5 \%$ are represented by $* * *$ and $* *$, respectively.

Given that there is a stable, long-run relationship between the relevant variables, it is possible to estimate an error correction model that captures both the short-and long-run behavior. The changes in the relevant variables represent short-run coefficients, while the coefficient on the ECM (error correction term) represents the speed of adjustment towards the long-run equilibrium point. The error correction coefficient is negative and statistically significant. It has been also observed that all variables are following long-term coefficients.

The estimation result of the Error Correction Model (ECM) shows that BDF, PS and FSD are found to have a positive and significant short-term effect with growth of external debt stock which is in line with the theoretical proposition. LNGDP and Open are insignificant in the short run, but with expected sign. The results also reveal a coefficient value for ECT $(-1)$ of 0.77 implying rejections of the null hypothesis of no cointegration. This represents the speed of adjustment from the short- run equilibrium to the long-run equilibrium and suggests that $77 \%$ of the short-term deviation of the external debt variable from their long-run is eliminated annually. This adjustment speed implies that it will take approximately one year and a half to bring the economy back to equilibrium

\section{CONCLUDING REMARKS}

The main objective of this study is to examine the principal determinant of external debt Ethiopia for the period 1981-2018 using descriptive and time series Econometric Analysis. The descriptive analysis result shows that the evolution of total debt stock, debt to GDP ratio and debt service to export ratio has been increasing at an increasing rate. We also employ ARDL bound testing approach as a method of analysis. After conducting all the necessary 
time series diagnostic tests, including model stability and bound testing to check the existence of cointegrration in the ARDL model. The result of this study shows that GDP growth affects the external debt stock growth of Ethiopia positively and significantly in the long run. The stagnated productivity growth caused by unproductive public spending and inefficient fiscal management aggravates country's increasing reliance on foreign borrowing and hence risk of external debt distress reaches at a high level. Moreover, looming macroeconomic imbalance and decrease in remittances and FDI inflow extend the economy's dependence on external debt in the long run. The result also revealed that Government budget deficit and political instability do have a positive and significant influence on the growth of external debt stock both in the short and long run.

In contrast, the effect of the degree of openness and infrastructural expenditure is found to be positive and significant, implying that both will increase the productivity and repayment capacity of the country in the future. Consequently, government should boost the share of tax and non-tax revenue through fostering taxpayer education, encouraging voluntary tax compliance, and strengthening enforcement efforts. Domestic resource mobilization in Ethiopia has been challenged by several factors such as illicit capital flight, slow structural transformation in the economy and tax avoidance by MNCs among others. Therefore, the government should work on policy reforms to control illicit capital flight and revise presumptive tax schemes to ensure cost-effective means of repaying debt. Furthermore, government should focus on channeling non-concessional debt proceeds towards bankable projects, initiating a public-private partnership (PPP) framework to bring active participation of the private sector on board. Developing and maintaining strong institutions, reduce heavy reliance on commodity export and diversify the economic structure via industrialization is also important long run policy options to reverse the situation

\section{REFERENCES}

Ada,M. and Kharusi,S (2018) "External Debt and Economic Growth: The Case of Emerging Economy", Journal of Economic Integration, Vol.33 No.1, March 2018, 1141 1157

Africa Development Bank (2018). "Federal Democratic Republic of Ethiopia Country StrategyPaper 2016-2020" EARC, Department.

Africa Economic Outlook (2018)"Report on Macroeconomic Performance and Prospects", Africa Development Bank, Abidjan, Côte d'Ivoire.

Alemayehu Geda (2020) "The Macroeconomic and Social Impact of COVID-19 in Ethiopia and Suggested Direction for Policy Response", Departemnent of Economics, Addis Ababa University

Alemayehu Geda and Daniel Zerfu, (1998) “profile of Ethiopian debt”, prepared for 8th annualconference on the Ethiopian economy, Addis Ababa, Ethiopia.

Alemayehu Geda, Daniel Zerfu and Ndung"u,N. (2012), Applied Time Series Econometrics: APractical Guide for Macroeconomic Researchers with a focus on Africa, University of Nairobi press, Central Bank of Kenya and AERC.

Alemayehu,G (1997). The Historical Origin of African Debt and Financial Crisis, ISS WorkingPaper, 62, The Hague.

Befkadu, D. (1992). Growth and Foreign Debt: The Ethiopian experience1964-86, AERC Research paper 13, Nairob

Bekhet, H.A., Matar, A. (2013), Co-integration and causality analysis between stock market 
prices and their determinates in Jordan. Economic Modelling, 35, 508-514. https://doi.org/10.1016/j.econmod.2013.07.012

Belguith and Omrane (2017) "Macroeconomic determinants of public debt growth: A case study for Tunisia" Theoretical and Applied Economics, Volume XXIV (2017), No. 4(613), Winter, pp.161-168.

Bentzen, J. \& T. Engsted (2001), "A Revival of the Autoregressive Distributed Lag Model in Estimating Energy Demand Relationships", Energy, 26(1), 45-55.

Checherita, C. and P. Rother (2010): "The impact of high and growing government debt on economic growth - an empirical investigation for the euro area", ECB Working Paper No. 1237, forthcoming in European Economic Review.

Chenery, H.B. and Strout, A.M. (1966) 'Foreign Assistance and Economic Development', American Economic Review 56(4)

Cooray, A. Dzhumashev, R. and Scneider, F. (2016) "How Does Corruption Affect Public Debt?An Empirical Analysis", World Development.

Corden. W.H. (1989) "Debt Relief and Adjustment initiatives" in J.A. Frenkel, M.P.Dooley and P. Wickam (Eds.), Analytical Issues in Debt, IMF, Washington. D.C.

Cukierman, A. and Meltzer, A. (1989) "A Political Theory of Government Debt and Deficits in aNeo-Ricardian Framework", American Economic Review, 79 (4), pp. 713-732.

Edwards, Sebastian and Guido, Tabellini (1991) "Explaining Fiscal Policies and Inflation in Developing Countries", Journal of International Money and Finance 10:1, S16-S48.

FDRE Ministry of Finance Annual Public Sector Debt Portfolio Report for the Year 2017/18 No. 19

Fry, M. J (1989) "Foreign debt instability: An analysis of national saving and domestic investment response to foreign debt accumulation in 28 developing countries", Journal of International Money and Finance, 8, 315-344.

Garedew,A (2018). " The relationship between public external debt and economic growth in ethiopia: evidence from ARDL approach to co-integration"

Hailemariam, A. (2011) " Impact of external debt on economic growth and private investment in Ethiopia", Paper submitted to the 9thinternational conference on Ethiopian economy

Hassan,S, Minga Negash, Tesfaye T. Lemma and Abu Girma Moges (2014) "Is Ethiopia's Sovereign Debt Sustainable\|?

Imbeau, L.M. and Pe'try, F (2004) "Politics, Institutions, and Fiscal Policy: Deficits and Surpluses in the Federated States", Lanham, MD: Lexington Books.

IMF (2019) "Staff Report for the 2018 Article IV Consultation-Debt Sustainability Analysis onEthiopia" Washington, D.C.

IMF Country Report No. 19/71, Malaysia, 2019 Article Iv Consultation-Press Release; Staff Report; And Statement By The Executive Director For Malaysia.

International Monetary Fund, 2018 Article Iv Consultation-Press Release; Staff Report; And Statement By The Executive Director For The Federal Democratic Republic Of Ethiopia; IMF Country Report No. 18/354

Johansen, S. \& Juselius, K. (1990) "Maximum likelihood estimation and inference on cointegration with application to the demand for money", Oxford Bulletin of Economics and Statistics, 52, pp. $169-210$.

Johansen, S. (1998) "Estimation and hypothesis testing of co-integration vectors in Gaussian vector authoregressive models", Econometrica, 59, pp. 1551-1580.

Jonse,G.(2002) “ External Debt and Economic Growth in Ethiopia “, Unpublished Thesis, Department of Economics, Addis Ababa University 
Krugman, P. (1988) "Financing versus Forgiving a Debt Overhang", Journal of Development Economics 29: 253-268

Lavigne, R.( 2011) "The political and institutional determinants of fiscal adjustment: Entering and exiting fiscal distress" European Journal of Political Economy, Vol. 27, Issue 1, March 2011, pp. 17-35.

Matiti, C.M. (2013) “ The effect of selected determinants on public debt in Kenya". MBA Project. Nairobi: University of Nairobi

Matošec, 2016. "Public Debt-to-GDP Ratio in New EU Member States: Cut the Numerator or Increase the Denominator?," Journal for Economic Forecasting vol. 0(3), pages 5772.

Melese, G.(2005) "External Debt and Economic Growth in Ethiopia", African Institute for Economic Deveopment and Planning (IDEP), Dakar (Sénégal)

MOFEC (2018) “Annual Public Sector Debt Portfolio Report for the Year 2017/18”, debt management directorate ministry of finance federal democratic republic of Ethiopia

Moodys (2014). Moodys investor Service, WWW. Moodys.com

NBE (2018/19) "Annual Report on the Ethiopian Economy", National Bank of Ethiopia.

Nguyen, V. (2015) "Effects of Public Debt on inflation in developing economies of Asia: Anempirical evidence based on panel differenced GMM Regression and PMG Estimation"

Oxfam (1997). "Poor Countries Debt Relief: false dawn or New Hope for Poverty Reduction?"Oxfam Policy papers.

P. Diamond. Cambridge: Cambridge University Press.

Peng Lee and Ling Ng (2015). "public debt and economic growth in malaysia" Asian Economicand Financial Review, 2015, 5(1): 119-126

Pesaran, M. H. and Shin, Y. (1995) "An autoregressive distributed lag modeling approach tocointegration analysis. In Centennial Volume of Ranger Frisch edited by S. Storm, A. Holly and

Pesaran, M.H. \& Y. Shin \& R.J. Smith (2001) "Bounds Testing Approaches to the Analysis ofLevel Relationships", Journal of Applied Econometrics, 16(3), 289-326.

Reinhart, C. M. and K. S. Rogoff (2010) "Growth in a Time of Debt", American Economic Review: Papers \& Proceedings 100 (May 2010): 573-578

Reinhart, C.M. and Kenneth S. Rogoff (2013) "Financial and Sovereign Debt Crises: SomeLessons Learned and Those Forgotten", IMF working Paper, WP/13/266.

Sachs, J. (1989) "The Debt Overhang of Developing Countries". In Calvo, G. A., Findlay, R., Kouri, P., Macedo, J. B. (Eds.), Debt Stabilization and Development: Essays in Memory ofCarlos Diaz-Alejandro: 80-102. Oxford and Cambridge, MA: Blackwell.

Salih. S.A. (1994) "Impacts of Africa's Growing Debt on its Growth", UNU/ WIDER

Uzun. A et al. (2012): "The Impacts of External Debt on Economic Growth in TransitionEconomies", Chinese Business Review, ISSN 1537-1506, May 2012, Vol. 11, Nr. 5, page 491- 99

Veiga and Tiago (2014). "Public Debt, Economic Growth, and Inflation in African Economies”,MPRA Paper No. 57377. 
African Journal of Economics and Sustainable Development

ISSN: 2689-5080

Volume 4, Issue 2, 2021 (pp. 1-28)

www.abjournals.org

\section{ANNEXES}

\section{Annex 1: Unit Root (ADF) Test at Level}

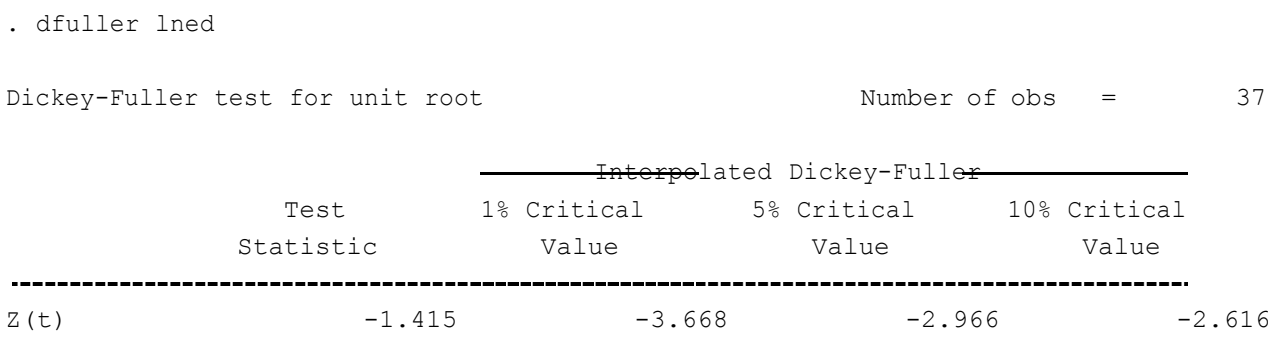

Mackinnon approximate $\mathrm{p}$-value for $\mathrm{Z}(\mathrm{t})=0.5752$

- dfuller lnpcgdp

Dickey-Fuller test for unit root

Number of obs =

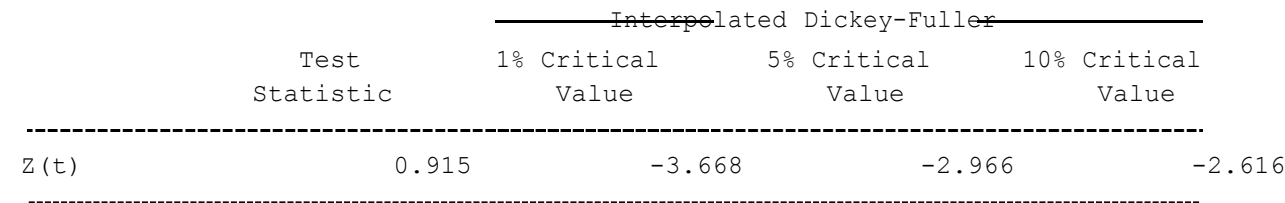

Mackinnon approximate $\mathrm{p}$-value for $\mathrm{Z}(\mathrm{t})=0.9933$

- dfuller open

Dickey-Fuller test for unit root

Number of obs $=37$

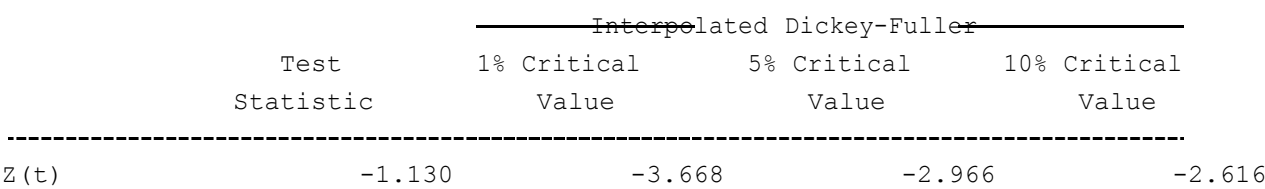

MacKinnon approximate $\mathrm{p}$-value for $\mathrm{Z}(\mathrm{t})=0.7031$

- dfuller bdf

Dickey-Fuller test for unit root

Number of obs $=37$

\begin{tabular}{|c|c|c|c|c|c|c|c|}
\hline \multirow{2}{*}{\multicolumn{2}{|c|}{$\begin{array}{c}\text { Test } \\
\text { Statistic }\end{array}$}} & \multicolumn{6}{|c|}{ Interplated Dickey-Fuller } \\
\hline & & $1 \%$ & $\begin{array}{l}\text { Critical } \\
\text { Value }\end{array}$ & $5 \%$ & $\begin{array}{c}\text { Critical } \\
\text { Value }\end{array}$ & $10 \%$ & $\begin{array}{c}\text { Critica } \\
\text { Value }\end{array}$ \\
\hline$z(t)$ & -2.977 & & -3.668 & & & & \\
\hline
\end{tabular}

MacKinnon approximate $p$-value for $Z(t)=0.0371$ 
African Journal of Economics and Sustainable Development

ISSN: $2689-5080$

Volume 4, Issue 2, 2021 (pp. 1-28)

www.abjournals.org

- dfuller infra

Dickey-Fuller test for unit root

Number of obs =

37

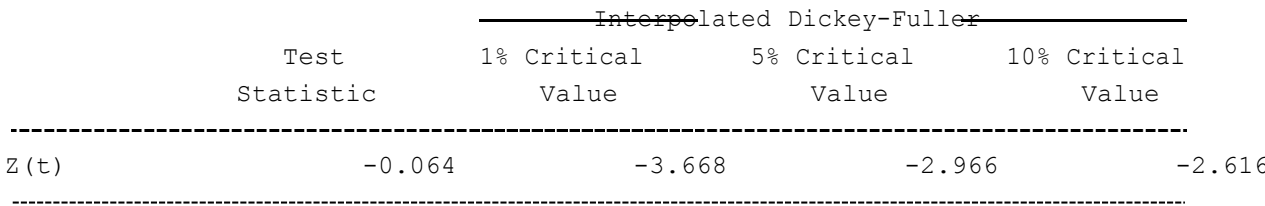

Mackinnon approximate $\mathrm{p}$-value for $\mathrm{Z}(\mathrm{t})=0.9529$

- dfuller ps

Dickey-Fuller test for unit root

Number of obs $=37$

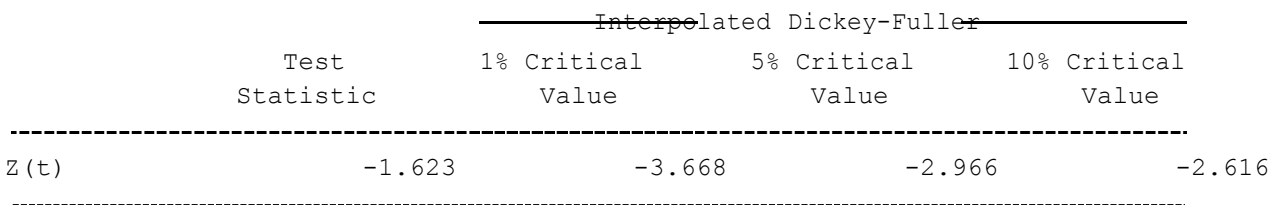

MacKinnon approximate $\mathrm{p}$-value for $\mathrm{Z}(\mathrm{t})=0.4711$

- dfuller adr

Dickey-Fuller test for unit root

Number of obs

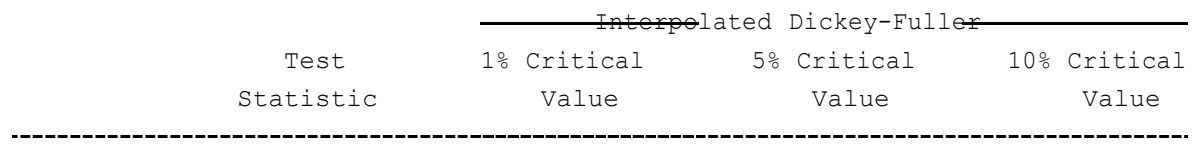

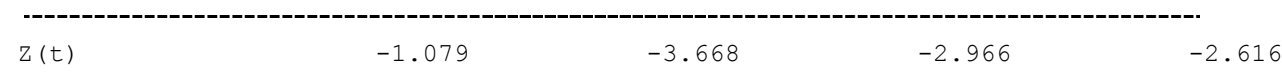

Mackinnon approximate $\mathrm{p}$-value for $\mathrm{Z}(\mathrm{t})=0.7236$

dfuller fsd

Dickey-Fuller test for unit root

Number of obs =

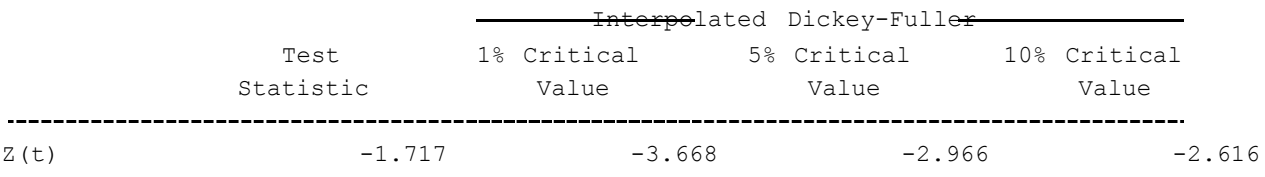

Mackinnon approximate $p$-value for $\mathrm{Z}(\mathrm{t})=0.4224$

- dfuller unp

$\begin{array}{lll}\text { Dickey-Fuller test for unit root } & \text { Number of obs }=37\end{array}$

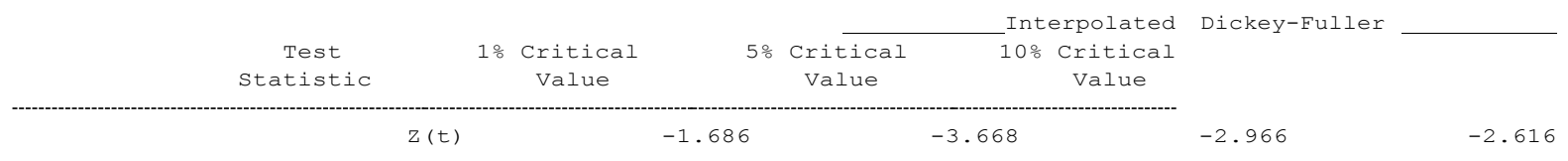

Mackinnon approximate $p$-value for $\mathrm{z}(\mathrm{t})=0.4382$ 
African Journal of Economics and Sustainable Development

ISSN: 2689-5080

Volume 4, Issue 2, 2021 (pp. 1-28)

www.abjournals.org

\section{Unit Root (ADF) Test at First Difference}

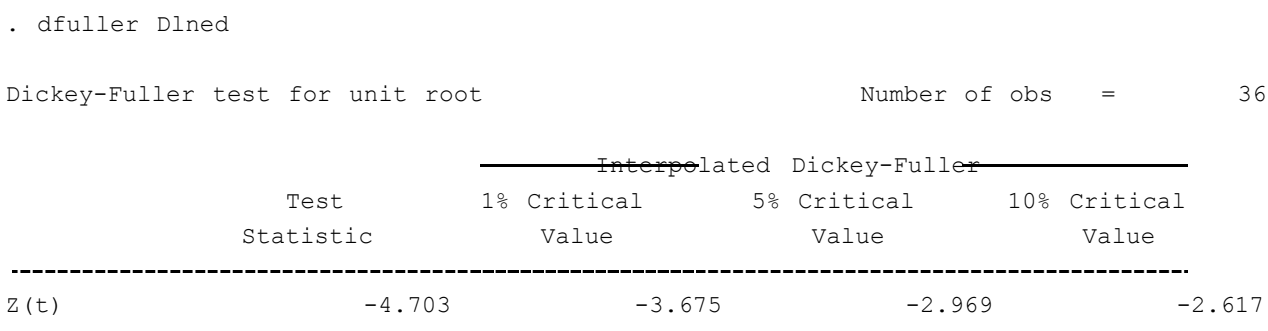

Mackinnon approximate $\mathrm{p}$-value for $\mathrm{Z}(\mathrm{t})=0.0001$

- dfuller Dlnpcgdp

Dickey-Fuller test for unit root

Number of obs $=36$

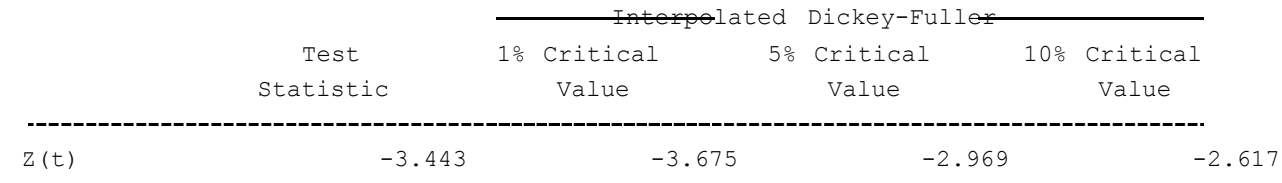

Mackinnon approximate $p$-value for $Z(t)=0.0096$

- dfuller Dbdf

Dickey-Fuller test for unit root

Number of obs $=36$

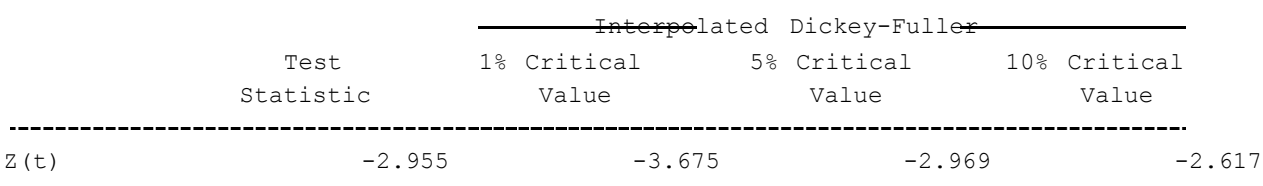

Mackinnon approximate $p$-value for $z(t)=0.0393$

- dfuller Dopen

Dickey-Fuller test for unit root Number of obs $=36$

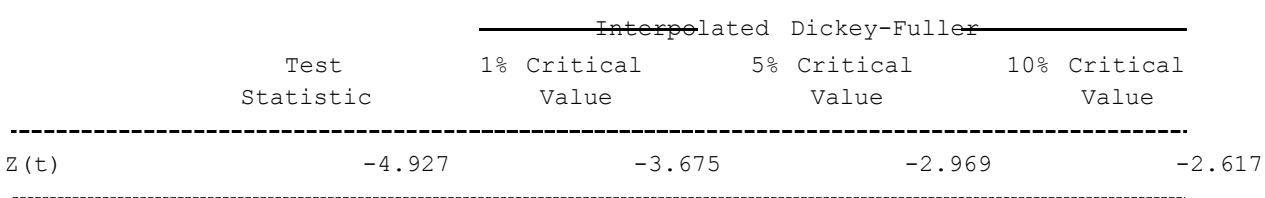

MacKinnon approximate $p$-value for $\mathrm{Z}(\mathrm{t})=0.0000$ 
African Journal of Economics and Sustainable Development

ISSN: $2689-5080$

Volume 4, Issue 2, 2021 (pp. 1-28)

www.abjournals.org

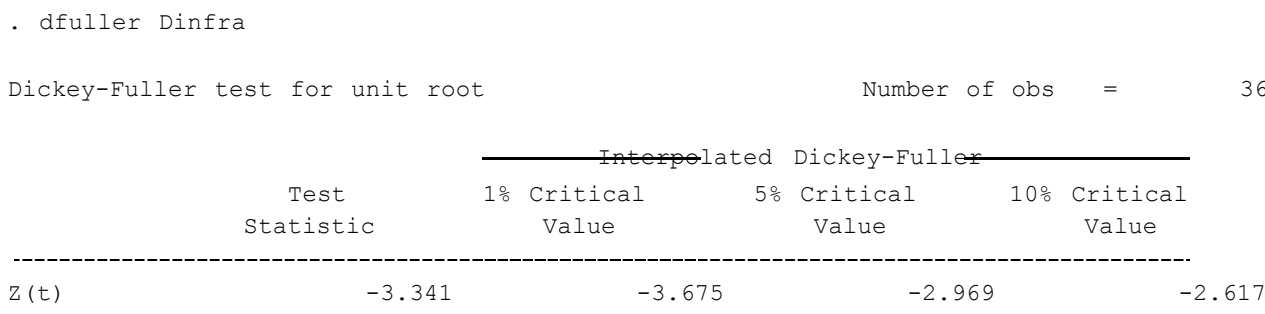

Mackinnon approximate $\mathrm{p}$-value for $\mathrm{Z}(\mathrm{t})=0.0131$

dfuller Dunp

Dickey-Fuller test for unit root $\quad$ Number of obs $=36$

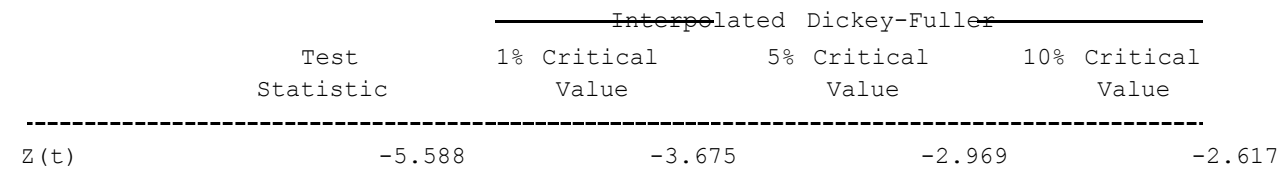

Mackinnon approximate $\mathrm{p}$-value for $\mathrm{Z}(\mathrm{t})=0.0000$

- dfuller Dps

Dickey-Fuller test for unit root Number of obs $=36$

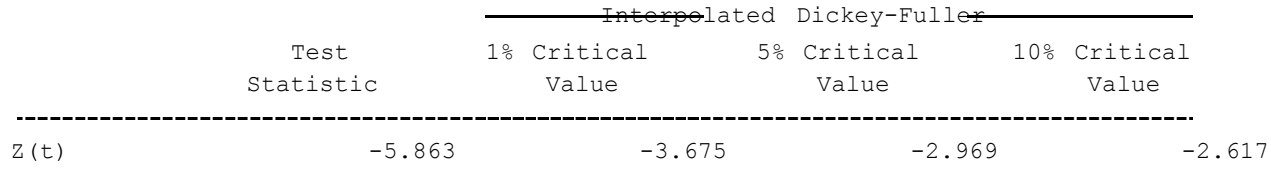

Mackinnon approximate $p$-value for $Z(t)=0.0000$

. dfuller Dadr

Dickey-Fuller test for unit root Number of obs $=36$

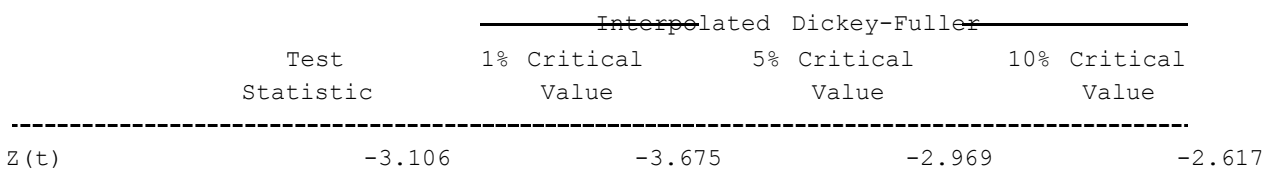

Mackinnon approximate $p$-value for $Z(t)=0.0261$

- dfuller Dfsd

$\begin{array}{lll}\text { Dickey-Fuller test for unit root } & \text { Number of obs }=36\end{array}$

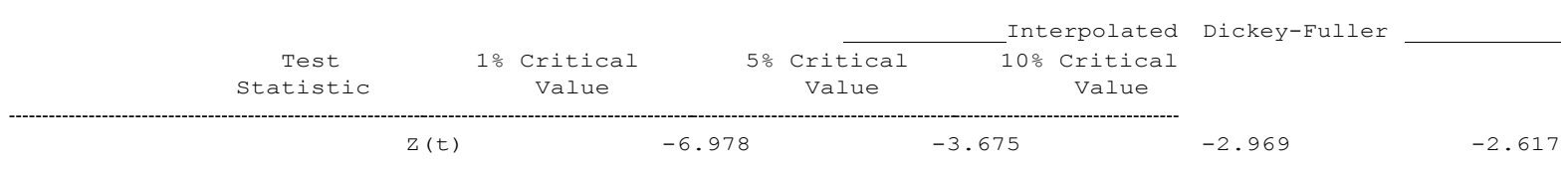

Mackinnon approximate $p$-value for $\mathrm{z}(\mathrm{t})=0.0000$ 
African Journal of Economics and Sustainable Development

ISSN: 2689-5080

Volume 4, Issue 2, 2021 (pp. 1-28)

www.abjournals.org

\section{Annex 2: Test for normality of residuals $(p=0.672702)$}

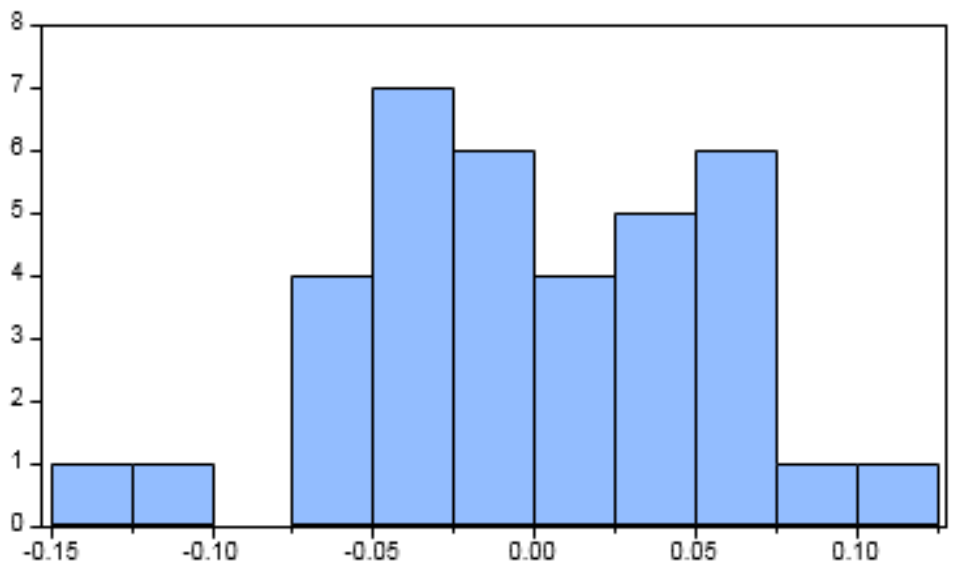

\begin{tabular}{|lr|}
\hline \multicolumn{2}{|l|}{ Series: Residuals } \\
Sample 1983 2018 \\
\multicolumn{2}{|l|}{ Observations 36} \\
Mean & $-2.17 \mathrm{e}-15$ \\
Median & -0.003894 \\
Maximum & 0.104511 \\
Minimum & -0.129520 \\
Std. Dev. & 0.055432 \\
Skewness & -0.238070 \\
Kurtosis & 2.450551 \\
& \\
Jarque-Bera & 0.792905 \\
Probability & 0.672702 \\
\hline
\end{tabular}

\section{Annex 3: Maximum Lag Length}

VAR Lag Order Selection Criteria

Endogenous variables: LNED LNPCGDP OPEN INFRA BDFUNP PS ADR FSD

Exogenous variables: C Date: 05/01/20 Time: 11:23Sample: 19812018

Included observations: 36

\begin{tabular}{ccccccc}
\hline Lag & LogL & LR & FPE & AIC & SC & HQ \\
\hline 0 & $-390.3681 \mathrm{NA}$ & 0.034957 & 22.18712 & 22.58300 & 22.32529 \\
1 & -101.9392416 .6195 & $3.96 \mathrm{e}-07$ & 10.66329 & $14.62209^{*}$ & 12.04502 \\
2 & $33.52386127 .9373^{*}$ & $4.88 \mathrm{e}-08^{*}$ & $7.637563 *$ & 15.15928 & $10.26284^{*}$ \\
\hline \hline
\end{tabular}

* indicates lag order selected by the criterion

- varsoc lned lnpcgdp open infra bdf unp ps adr fsd, maxlag(3)

\begin{tabular}{|c|c|c|c|c|c|c|c|c|}
\hline \multirow[t]{6}{*}{ Sample: } & \multicolumn{5}{|c|}{$1984-2018$} & \multicolumn{2}{|c|}{ Number of obs } & $=$ \\
\hline & $\operatorname{lag}$ & $\mathrm{LL} \quad \mathrm{LR}$ & $d f$ & $\mathrm{p}$ & $\mathrm{FPE}$ & AIC & $\mathrm{HQIC}$ & SBIC \\
\hline & 0 & -374.823 & & & .027106 & 21.9327 & 22.0708 & 22.3327 \\
\hline & 1 & -93.4084562 .83 & 81 & 0.000 & $3.3 e-07$ & 10.4805 & 11.8611 & 14.4799 \\
\hline & 2 & $56.2062299 .23 *$ & 81 & 0.000 & $1.9 e-08$ & $6.55964 *$ & $9.18281 *$ & $14.1586 *$ \\
\hline & 3 & . & 81 & & $-1.6 e-39 x$ & & . & . \\
\hline
\end{tabular}

Endogenous: Ined lnpcgdp open infra bdf unp ps adr fsdExogenous: _cons 


\section{Annex 4: Model Specification Test}

Ramsey RESET Test Equation: UNTITLED

Specification: LNED LNED(-1) LNED(-2) LNPCGDP OPEN OPEN(-1) OPEN(-2) INFRA BDF BDF(-1) UNP UNP(-1) UNP(-

2) PS PS(-1) ADR ADR(-1) ADR(-2) FSD FSD(-1) FSD(-2) C

\begin{tabular}{lccc}
\hline & Value & df & Probability \\
\cline { 2 - 4 } F-statistic & 0.346212 & $(5,10)$ & 0.8734 \\
\hline
\end{tabular}

F-test summary:

\begin{tabular}{|c|c|c|c|}
\hline & $\begin{array}{c}\text { Sum of } \\
\text { Sq. }\end{array}$ & $\mathrm{df}$ & $\begin{array}{l}\text { Mean } \\
\text { Squares }\end{array}$ \\
\hline Test SSR & 0.015869 & 5 & 0.003174 \\
\hline Restricted SSR & 0.107543 & 15 & 0.007170 \\
\hline Unrestricted SSR & 0.091674 & 10 & 0.009167 \\
\hline
\end{tabular}

\section{Annex 5: Test for serial correlation}

Breusch-Godfrey Serial Correlation LM Test:

\begin{tabular}{llll}
\hline F-statistic & 0.700375 & Prob. F(2,13) & 0.5142 \\
Obs*R-squared & 3.501695 & Prob. Chi-Square(2) & 0.1736
\end{tabular}

\section{Annex 6 : Test for Hetroscedasticity}

Heteroskedasticity Test: ARCH

\begin{tabular}{llll}
\hline F-statistic & 0.347488 & Prob. F(2,31) & 0.7092 \\
Obs*R-squared & 0.745519 & Prob. Chi-Square(2) & 0.6888
\end{tabular}


African Journal of Economics and Sustainable Development

ISSN: 2689-5080

Volume 4, Issue 2, 2021 (pp. 1-28)

\section{Annex 7: Bound Test (Cointegration Test)}

ARDL Bounds Test

Date: 04/30/20 Time: 13:21Sample: 19832018

Included observations: 36

Null Hypothesis: No long-run relationships exist

Test Statistic Value k

F-statistic $\quad 9.147911 \quad 8$

Critical Value Bounds

\begin{tabular}{lcc}
\hline Significance & I0 Bound & I1 Bound \\
\hline $10 \%$ & 1.95 & 3.06 \\
$5 \%$ & 2.22 & 3.39 \\
$2.5 \%$ & 2.48 & 3.7 \\
$1 \%$ & 2.79 & 4.1 \\
\hline
\end{tabular}

\section{Annex 8: Structural Break Test}

Chow Breakpoint Test: 2008

Null Hypothesis: No breaks at specified breakpoints Varying regressors: All equation variables

Equation Sample: 19812018

\begin{tabular}{llll}
\hline F-statistic & 0.100051 & Prob. F(8,22) & 0.9989 \\
Log likelihood ratio & 1.357974 & Prob. Chi-Square(8) & 0.9948 \\
Wald Statistic & 0.800412 & Prob. Chi-Square(8) & 0.9992
\end{tabular}


African Journal of Economics and Sustainable Development

ISSN: 2689-5080

Volume 4, Issue 2, 2021 (pp. 1-28)

www.abjournals.org

\section{Annex 8: ARDL Estimation Result}

ARDL Cointegrating And Long Run FormDependent Variable: LNED

Selected Model: ARDL(2, 0, 2, 0, 1, 2, 1, 2, 2)

Date: 04/30/20 Time: 13:12Sample: 19812018

Included observations: 36

Cointegrating Form

\begin{tabular}{lrr}
\hline Variable & CoefficientStd. Error & \multicolumn{1}{c}{ t-StatisticProb. } \\
\hline D(LNED(-1)) & -0.1311880 .080235 & -1.6350360 .1228 \\
D(LNPCGDP) & 0.2087020 .138762 & 1.5040260 .1533 \\
D(OPEN) & -0.0086190 .008093 & -1.0650320 .3037 \\
D(OPEN(-1)) & 0.0124080 .007086 & 1.7510890 .1003 \\
D(INFRA) & -0.1745380 .058305 & -2.9935370 .0091 \\
D(BDF) & 0.0801920 .015210 & 5.2723140 .0001 \\
D(UNP) & -0.5625710 .091113 & -6.1744170 .0000 \\
D(UNP(-1) & -0.0969270 .051908 & -1.8673060 .0815 \\
D(PS) & 0.2118660 .032012 & 6.6182510 .0000 \\
D(ADR) & 0.6606910 .799595 & 0.8262820 .4216 \\
D(ADR(-1)) & -1.6437020 .766276 & -2.1450520 .0487 \\
D(FSD) & 0.0286580 .006248 & 4.5864260 .0004 \\
D(FSD $(-1))$ & 0.0267540 .008358 & 3.2011860 .0059 \\
CointEq(-1) & -0.7719010 .152019 & -5.0776680 .0001
\end{tabular}

Cointeq $=$ LNED $-(0.2704 *$ LNPCGDP $-0.0202 *$ OPEN $0.2261 *$ INFRA + 0.1427*BDF $0.2790 * \mathrm{UNP}+0.1365 * \mathrm{PS}+$ $1.0544 * \mathrm{ADR}+0.0160 * \mathrm{FSD}-1.2694$ )

Long Run Coefficients

\begin{tabular}{crr}
\hline Variable & CoefficientStd. Error & \multicolumn{1}{c}{ t-StatisticProb. } \\
\hline LNPCGDP & 0.2703740 .154260 & 1.7527130 .1001 \\
OPEN & -0.0201770 .007596 & -2.6561490 .0180 \\
INFRA & -0.2261150 .038301 & -5.9036940 .0000 \\
BDF & 0.1426690 .033446 & 4.2657070 .0007 \\
UNP & -0.2789700 .114452 & -2.4374370 .0277 \\
PS & 0.1365300 .049763 & 2.7435730 .0151 \\
ADR & 1.0543560 .693694 & 1.5199150 .1493 \\
FSD & 0.0160120 .016145 & 0.9917500 .3370 \\
C & -1.2694093 .663362 & -0.3465150 .7338 \\
\hline
\end{tabular}




\section{Annex 9: OLS Estimation Result}

Dependent Variable: LNED Method: Least Squares Date: 09/29/20 Time: 22:15Sample: 19812018

Included observations: 38

\begin{tabular}{|c|c|c|c|c|}
\hline Variable & Coefficient & Std. Error & \multicolumn{2}{|c|}{ t-StatisticProb. } \\
\hline $\mathrm{C}$ & 9.523645 & 3.958938 & 2.405606 & 0.0227 \\
\hline LNPCGDP & 0.581455 & 0.200924 & 2.893911 & 0.0072 \\
\hline OPEN & -0.003591 & 0.010048 & -0.357368 & 0.7234 \\
\hline INFRA & -0.298386 & 0.044771 & -6.664689 & 0.0000 \\
\hline $\mathrm{BDF}$ & 0.050325 & 0.023281 & 2.161623 & 0.0390 \\
\hline UNP & -0.044116 & 0.145359 & -0.303499 & 0.7637 \\
\hline PS & 0.064299 & 0.056721 & 1.133598 & 0.2662 \\
\hline $\mathrm{ADR}$ & -1.371724 & 0.685036 & -2.002412 & 0.0547 \\
\hline FSD & 0.058803 & 0.011698 & 5.026788 & 0.0000 \\
\hline R-squared & \multicolumn{3}{|c|}{ 0.910852 Mean dependent var } & 3.899016 \\
\hline Adjusted R-squared & \multicolumn{3}{|c|}{ 0.886259S.D. dependent var } & 0.686575 \\
\hline S.E. of regression & \multicolumn{3}{|c|}{0.231551 Akaike info criterion } & 0.115358 \\
\hline Sum squared resid & \multicolumn{3}{|c|}{ 1.554857 Schwarz criterion } & 0.503208 \\
\hline Log likelihood & \multicolumn{3}{|c|}{ 6.808189Hannan-Quinn criter. } & 0.253352 \\
\hline F-statistic & \multicolumn{3}{|c|}{ 37.03761 Durbin-Watson stat } & 1.496399 \\
\hline Prob(F-statistic) & 0.000000 & & & \\
\hline
\end{tabular}


African Journal of Economics and Sustainable Development

ISSN: 2689-5080

Volume 4, Issue 2, 2021 (pp. 1-28)

www.abjournals.org

\section{Annex 10: Trend of Debt Stock Growth and Per Capita GDP Growth in Ethiopia}

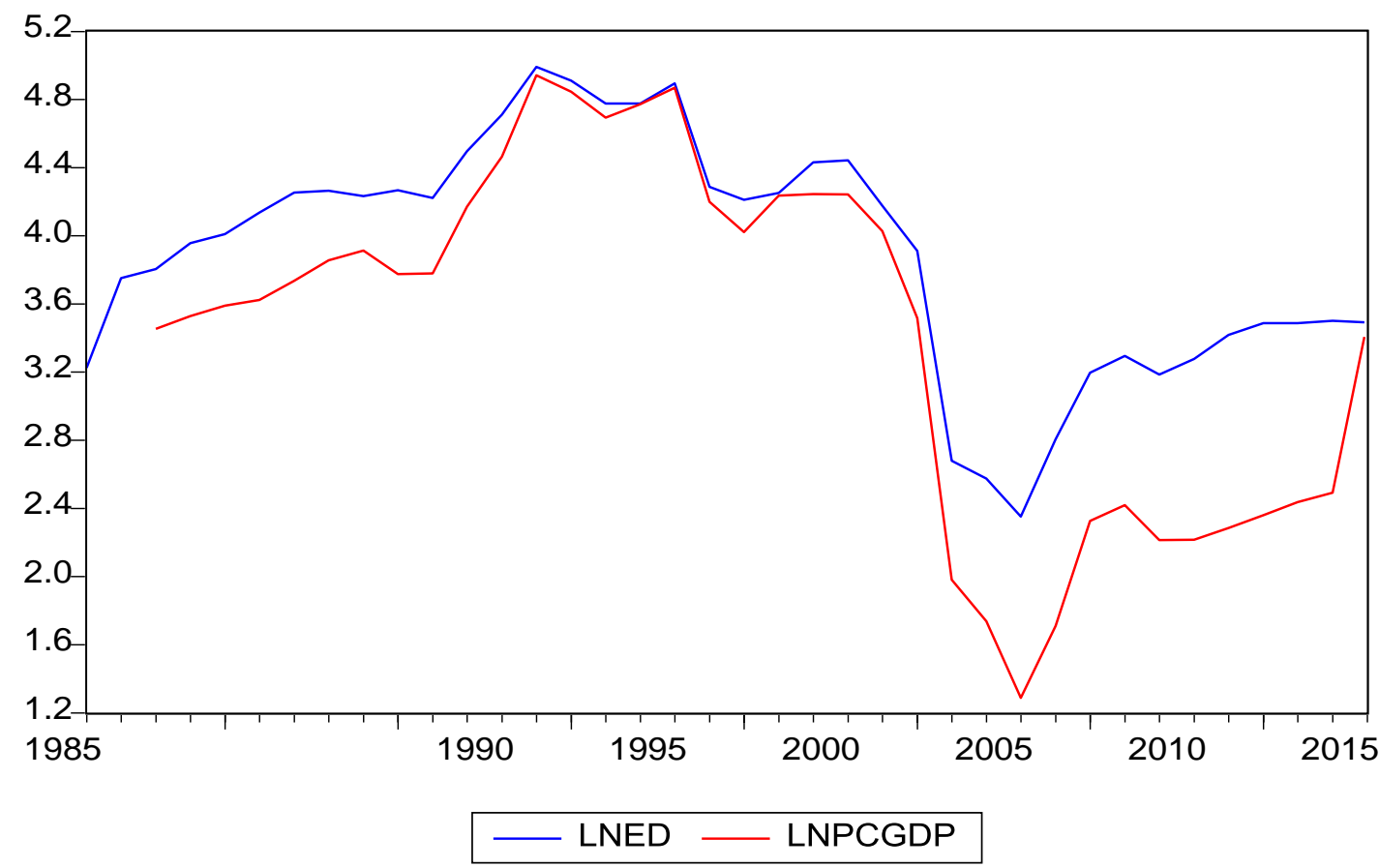

\section{Annex 11: Forecasting Accuracy Evaluation of the Model}

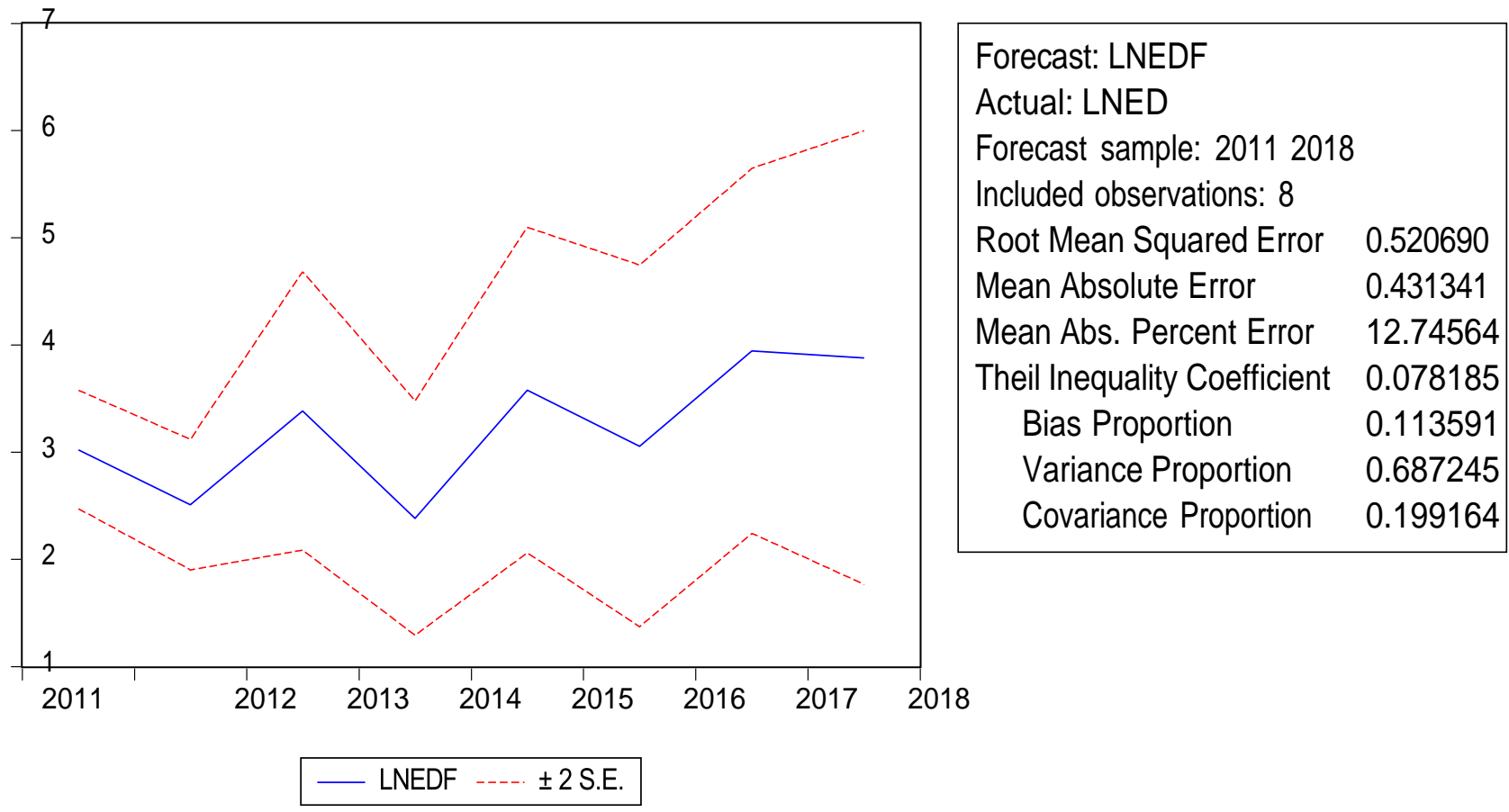

